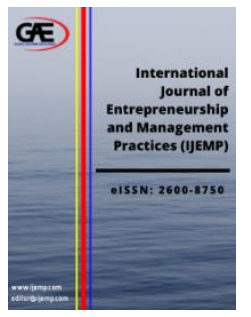

\author{
INTERNATIONAL JOURNAL OF \\ ENTREPRENEURSHIP AND \\ MANAGEMENT PRACTICES \\ (IJEMP) \\ www.ijemp.com
}

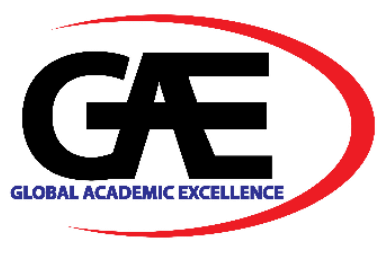

\title{
MAPPING THE FIELD: A BIBLIOMETRIC ANALYSIS OF EMPLOYEE VOICE
}

\author{
Jen Ling Gan ${ }^{1 *}$, Aqilah Yaacob ${ }^{2}$ \\ $1 \quad$ Taylor's University \\ Email: jenling.gan@taylors.edu.my \\ Taylor's University \\ Email: Aqilah.yaacob@taylors.edu.my \\ Corresponding Author
}

\section{Article Info:}

\section{Article history:}

Received date: 09.12.2020

Revised date: 30.12 .2020

Accepted date: 15.01.2021

Published date: 01.03.2021

\section{To cite this document:}

Gan, J. L., \& Yaacob, A. (2021). Mapping The Field: A Bibliometric Analysis Of Employee Voice. International Journal of Entrepreneurship and Management Practices, 4 (13), 01-21.

DOI: $10.35631 /$ IJEMP.413001.

This work is licensed under $\underline{\mathrm{CC} B Y 4.0}$

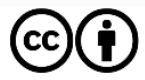

\begin{abstract}
:
Objective: There is limited literature that discussed the trend of 'employee voice'. Hence, this bibliometric analysis is aimed to evaluate the global research growth to retrieve and analyze the publication on 'employee voice'. The bibliometric analysis is used to search the database of Scopus from the oldest publication in 1986 to the recent publication in 2019. The objectives were to evaluate the trend of 'employee voice' research, details of coauthorship, leading institutions and countries, top scholars, and leading author keywords. Methodology: This study used VOS Viewer 1.6.11 to analyze and visualize the global research trend on 'employee voice' in analyzing the bibliographic data. Bibliometric maps were retrieved from VOS Viewer 1.6.11. Results: This study retrieved 443 journal articles from the Scopus database from 1986 to 2019. The publication's trend revealed that the number of publications has been increasing steadily since 2005 . The leading countries in 'employee voice' research are the United Kingdom and the United States. Among the fifteen leading universities, five of them were from the world's top 150 universities. Among the keywords, 'voice behavior' has the most linkage with 'employee voice', which indicated that employee voice is active in the business and management field compared to other fields such as nursing and psychology. According to the author keywords analysis, 'promotive voice' and 'prohibitive voice' were found to become a potential concerned area in the future as they started to receive attention in 2017. Implication: This paper can be beneficial for academicians, organizations, and business policymakers in understanding the global trend of 'employee voice' besides discovering the future directions and opportunities for future studies.
\end{abstract}

Keywords:

Bibliometric Analysis, Bibliographic Map, VOS Viewer, Employee Voice 


\section{Introduction}

In the past decades, the attention to people management has been lacking, especially in the aspect of employee voice (Wæraas and Dahle, 2020). The effect of employee voice has been recognized that it can help to improve employees' involvement which could in turn, enhancing the overall organizational performance (Marchington, 2015). Due to the benefits of employee voice, it therefore plays a vital role in employees' participation, engagement, as well as the communication with managerial team (Holland, Cooper, and Sheehan, 2017). Employee voice is defined as employees' attempt to make a change instead of escaping from the status quo (Wilkinson, Barry, and Morrison, 2019). Although employee voice is seemed as an important variable, the global trend of employee voice is yet to be researched. It is believed that the big picture of global trend could act as a guidance for future researcher in exploring new insight in employee voice research area. Therefore, this bibliometric analysis paper intended to outline the global trend of employee voice since 1986 to 2019.

Although the discussion of global trend in employee voice is lacking, Casey and McMillan (2019) had presented the research trend of employee voice from 1980s to the early of 2000s. As the scholars covered only till 2015 , there was a certain level of insufficiency of data, due to it did not cover till recent year, 2019. This could affect the comprehensiveness of the big picture of employee voice. In addition to that, Casey and McMillan (2019) conducted their data mining via the database of Web of Science (WOS). However, retrieving data from single database could be limited. Although WOS and Scopus database might have overlapped journal indexing, the two databases indexed different journals (Aghaei Chadegani et al., 2013). Furthermore, as compared to WOS, Scopus is known as the largest database that indexed multidisciplinary research. Therefore, this paper intended to minimize the gap of Casey and McMillan (2019) by conducting data mining via Scopus database.

By analyzing the data, this bibliometric analysis paper could be benefited to business policymakers, stakeholders of organizations, and academicians in comprehending the global trend of employee voice as well as the new directions for future researchers. Therefore, this paper consists of four purposes: (a) to examine the outline of trend in employee voice journal article; (b) to specify the contributions of productive scholars, institutions, and countries; (c) to explore the terminology, topic of interest, and concept of employee voice; and (d) to deliver new insight for future directions.

\section{Methods}

Bibliometric analysis is used in this research to examine the recent trends in the literature concerning the topic of Employee Voice. The results from this research are helpful in providing guidelines and motivations for upcoming research work in this area. Bibliometric analysis focuses on the performance of publications in a particular field such as understanding the research growth, most productive and highly cited authors, top journals and highly influential papers, which are different from a review paper (Cobo et al., 2011).

In particular, the authors collected bibliometric data from the most widely referred repositories which is the Scopus. From the Scopus, various data have been extracted including the author, title, abstract, country, citation record, and author affiliation. Besides that, we also retrieved several performance indicators for the bibliometric analysis such as: Total Papers (TP), which is the total number of publications from the source, Total Citations (TC), which is the total 
number of citations received by the publication, and Total Publications per Country (TPC), which is the total publications from the top leading countries.

\section{Searching Strategy}

Data mining was performed on $26^{\text {th }}$ October 2020 via Scopus by concentrating on the main theme around the research articles of 'Employee Voice'. This keyword has been used in the title and abstract to investigate the worldwide research tendency of Employee Voice.

All the journal papers were then organized by years, from the first article published in 1986 to the newest article published in 2019. The query string setting was as follows: (TITLE-ABS ( "employee voice" ) AND DOCTYPE ( ar ) AND PUBYEAR > 1986 AND PUBYEAR < 2019 AND ( LIMIT-TO ( SRCTYPE, "j" ) ). As a result, a total of 499 documents was discovered from this query string.

From the extracted documents in Scopus, the 499 documents also include non-empirical papers such as Conference Papers and Conference Reviews. However, these types of papers were irrelevant to be included in the bibliometric analysis. Hence, the authors have taken a further step to exclude all the non-empirical papers. This step was possible by including phrases such as "review", "progress", and "revisit" into the query string.

By conducting the data screening, the authors discovered 56 non-empirical papers. The next step taken by the authors were to record the EIDs (i.e. Scopus article identifier) of the 56 documents, which was then added to the subsequent search string. This was done in order to exclude these papers from further analysis. By removing the non-empirical papers, the authors managed to obtain 443 documents.

The 443 documents were then examined based on year, authors, country, affiliation, subject area, and source. The authors also gathered several indicators of bibliometric such as h-index and total citations to construct a ranking list. Figure 1 illustrated the procedure of the searching strategy. Further detailed of the query strings were added in the supplementary material section (Table S1). 


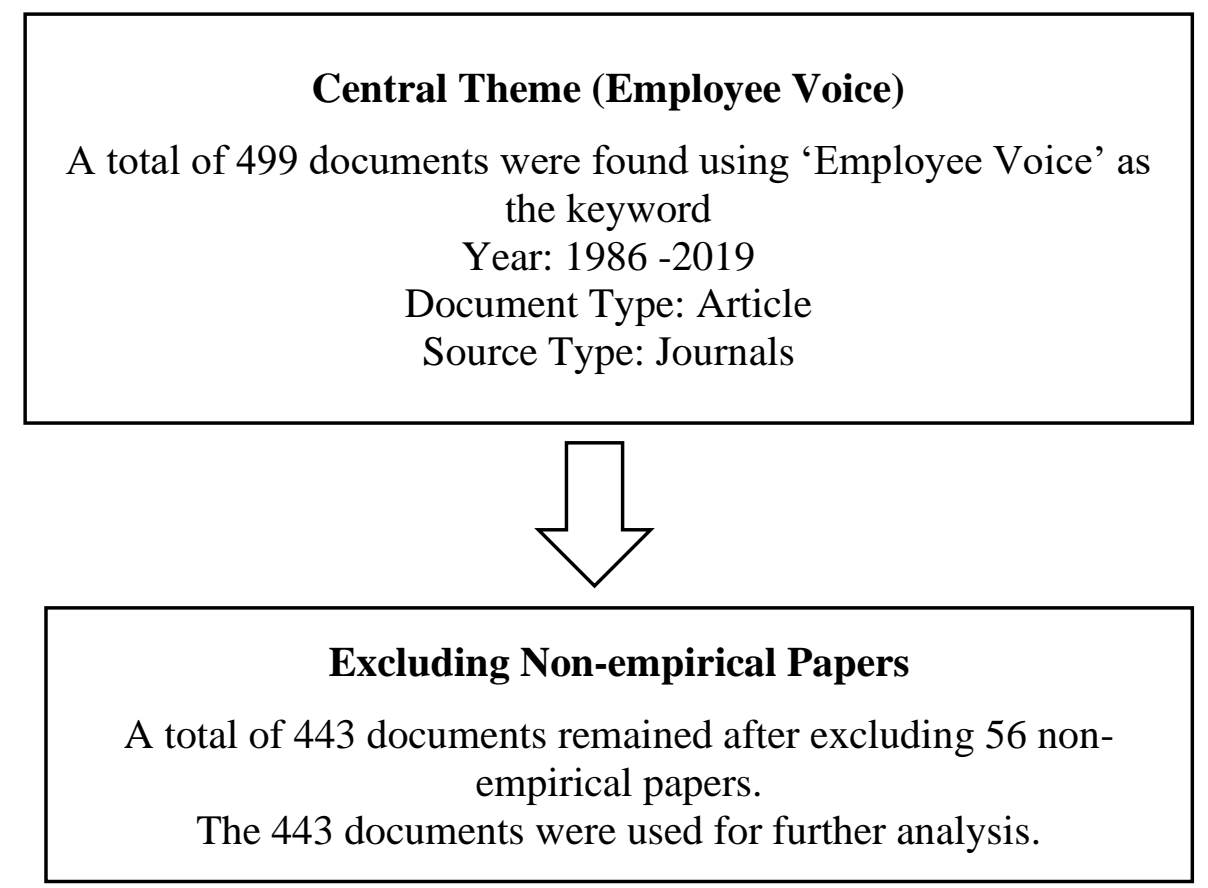

Figure 1: Data Collection of Employee Voice Publications

\section{Bibliometric Map}

For the next stage of the data analysis, the authors utilized VOSviewer version 1.6.11, in which the bibliographical information of 443 articles were exported. VOSviewer is an effective tool for the authors to visualise the bibliometric map as presented in the following sections. VOSviewer were able to present the leading countries and frequent author keywords in the context of Employee Voice. Further discussion on the bibliometric map will be discussed in Section 3.3 and Section 3.5.

\section{Co-authorship Analysis}

The findings from the co-authorship analysis suggested that the 49 countries were associated with 159 authors. The associated nations were grouped into nine regions including United States, United Kingdom, Middle East, Asia, Oceania, Europe, Eurasia, Africa, and Caribbean.

\section{Analysis of Co-occurrence}

The keyword co-occurrence analysis suggested 49 author keywords from 443 research papers. Prior to the author keywords analysis in VOS Viewer, the authors created a thesaurus file to identify any repeating keywords. In order to do that, the authors screened each of the author keywords and grouped the similar keywords together. For example, leader-member exchange has the same meaning with LMX, hence they were re-labelled as "LMX". The authors also set a minimum of five keywords occurrences to produce the output of analysis. 


\section{Results and Discussion}

\section{Research Growth}

Employee Voice has been gaining rapid attention since its inception in 1986. In total, there were 443 research papers published in the span of 33 years. Figure 2 demonstrates the growth of publications in Scopus. The first publication on Employee Voice came out in 1986 with one paper. However, there were no significant increase in published articles until 1997. From 1997 onwards, the number of publications in Employee Voice has been increased exponentially till it reached the maximum of 86 papers in 2019.

The research efforts on this matter starts to become more active in the year of 2005. The annual growth rate increased rapidly in 2005 when the number of publications was almost three times more than the publications in 1997. The increasing number of publications has resulted in the increased number of cumulative total publications.

From the publication analysis, we can see that the number of publications in the field of Employee Voice increased rapidly from 2009 to 2019. Within the time span of 10 years, the total publications increase from 10 journal articles in 2009 to 86 journal articles in 2019 . Employee Voice has begun to received attention and acknowledgment from researcher, which has led to the growing number of publications. These findings suggested that the study on Employee Voice will continue to increase in the future. As for 2019, only 8.6\% (38 articles) are open access articles, hence it is suggested that more journal papers should have public access to scholars in order to increase the rate of readability.

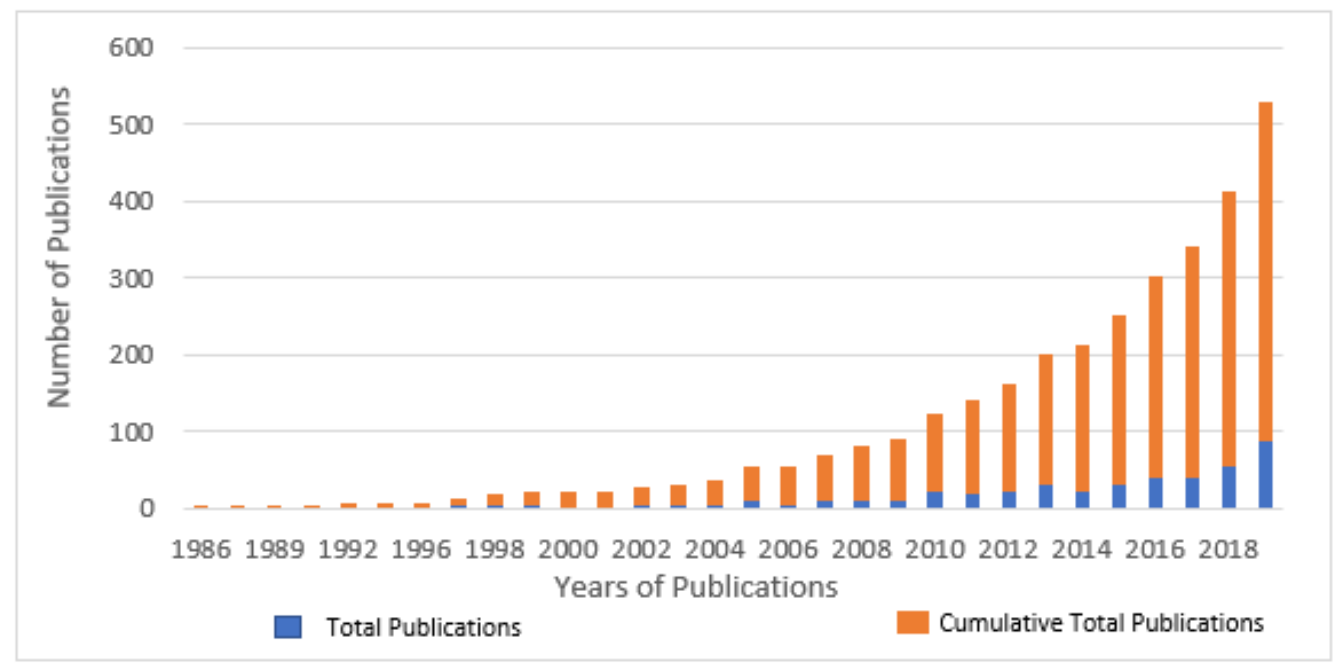

Figure 2: Annual Quantity of Employee Voice articles in Scopus database (1986 - 2019)

Based on the subject area analysis, we can see that Employee Voice received attention mainly from the business and social sciences field. This is evidence by the top five ranking of subject area suggested by Scopus, namely, Business, Management, and Accounting (352 articles), Social Sciences (124 articles), Psychology (90 articles), Economics, Econometrics, and Finance (42 articles), as well as Arts and Humanities (33 articles).

Besides the interest in business and social sciences area, Employee Voice received attention from another multidisciplinary field as well. For instances, 37 articles of Employee Voice were 
published in the field of Decision Sciences, Medicine and Environmental Science. These findings indicate that apart from publications in the obvious areas, there is a wider coverage of Employee Voice in various other disciplines, which demonstrate the much broader integration of the interdisciplinary works from various disciplines.

\section{Top Productive Journals Analysis}

In this section, the authors have extracted the top ten journals which were published most frequently in the context of Employee Voice. Table 1 compiled all the results concerning the total publication and total citation for the top ten journals from Scopus database. The leading journals were ranked according to the total number of publications.

As indicated in Table 1, the top ten leading journals were produced by eight different publishers. For instances, the top three productive journals were published by Taylor and Francis and SAGE Publications. Out of the eight publishers, SAGE Publications issued the highest number of journals, where three out of ten journals are from this publisher. The remaining journals were published by Taylor and Francis, American Psychological Association (APA), Wiley-Blackwell, Emerald Group Publishing Ltd., Society for Personality Research, Academy of Management, and Springer Nature. Most of the leading journals were in Quartile 1 (Q1) and only two journals were in Quartile 3 (Q3).

In Scopus, International Journal of Human Resource Management is the most productive journal. This journal has published the most papers (TP $=32$ ) which covered $7 \%$ of total publications in Employee Voice, followed by Economic and Industrial Democracy with 17 publications and Human Relations with 14 publications. Journal of Applied Psychology is ranked at $4^{\text {th }}$ place but has the second highest citation count of 910 with 14 publications.

The Human Resource Management Journal is ranked at 5 with 13 papers were being issued, which represent $2.94 \%$ of total publications in Employee Voice. This is followed by Journal of Industrial Relations (13, 2.94\%), Employee Relations (12, 2.71\%), and Social Behaviour and Personality $(11,2.49 \%)$. Interestingly, Academy of Management Journal is ranked at $9^{\text {th }}$ place for the top productive journal, but this journal has the highest citation count of 1364 with 9 publications. This is because one of the paper published in this journal has the most citation among the ten papers (792 citations).

Based on the CiteScore 2019 analysis, five journals managed to score more than 5.0 CiteScore. Academy of Management Journal had the highest CiteScore of 14.0, followed by Journal of Applied Psychology (10.7). The journal with the lowest CiteScore was Employee Responsibilities and Rights Journal (1.1) and Social Behavior And Personality (1.2).

According to Khudzari et al. (2018), it is essential for researchers to examine the CiteScore as it is one of the important criteria in selecting the most suitable journals to publish in. Therefore, in the effort of assisting future scholars, the authors have included a directory of the leading CiteScore journals in the supplementary material section (Table S2). 
Volume 4 Issue 13 (March 2021) PP. 01-21

DOI: 10.35631/LJEMP.413001

Table 1: Leading Journals on Employee Voice Studies (Based On Total Publication)

\begin{tabular}{|c|c|c|c|c|c|c|c|c|}
\hline Rank & Journal & Quartile & $\begin{array}{l}\mathrm{TP} \\
(\%)\end{array}$ & $\mathrm{TC}$ & $\begin{array}{l}\text { CiteScore } \\
2019\end{array}$ & $\begin{array}{l}\text { The most cited article } \\
\text { (Reference) }\end{array}$ & $\begin{array}{l}\text { Times } \\
\text { cited }\end{array}$ & Publisher \\
\hline 1 & $\begin{array}{l}\text { Internatio } \\
\text { nal } \\
\text { Journal of } \\
\text { Human } \\
\text { Resource } \\
\text { Managem } \\
\text { ent }\end{array}$ & Q1 & $\begin{array}{l}32 \\
(7.2 \\
3)\end{array}$ & $\begin{array}{l}79 \\
6\end{array}$ & 5.5 & $\begin{array}{l}\text { The meanings and } \\
\text { purpose of employee } \\
\text { voice (Dundon, } \\
\text { Wilkinson, } \\
\text { Marchington, } \\
\text { Ackers, 2004) }\end{array}$ & 215 & $\begin{array}{l}\text { Taylor \& } \\
\text { Francis }\end{array}$ \\
\hline 2 & $\begin{array}{l}\text { Economic } \\
\text { and } \\
\text { Industrial } \\
\text { Democrac } \\
\text { y }\end{array}$ & Q1 & $\begin{array}{l}17 \\
(3.8 \\
5)\end{array}$ & 76 & 3.0 & $\begin{array}{l}\text { Filling the gaps: } \\
\text { Patterns of formal } \\
\text { and informal } \\
\text { participation } \\
\text { (Townsend, } \\
\text { Wilkinson, Burgess, } \\
\text { 2013) }\end{array}$ & 35 & $\begin{array}{l}\text { SAGE } \\
\text { Publicatio } \\
\text { ns }\end{array}$ \\
\hline 3 & $\begin{array}{l}\text { Human } \\
\text { Relations }\end{array}$ & Q1 & $\begin{array}{l}14 \\
(3.1 \\
7)\end{array}$ & $\begin{array}{l}41 \\
5\end{array}$ & 7.1 & $\begin{array}{l}\text { Employee voice and } \\
\text { organizational } \\
\text { performance: Team } \\
\text { versus representative } \\
\text { influence (Kim, } \\
\text { MacDuffie, Pil, } \\
\text { 2010) }\end{array}$ & 68 & $\begin{array}{l}\text { SAGE } \\
\text { Publicatio } \\
\text { ns }\end{array}$ \\
\hline 4 & $\begin{array}{l}\text { Journal of } \\
\text { Applied } \\
\text { Psycholog } \\
\text { y }\end{array}$ & Q1 & $\begin{array}{l}14 \\
(3.1 \\
7)\end{array}$ & $\begin{array}{l}91 \\
0\end{array}$ & 10.7 & $\begin{array}{l}\text { Leader Personality } \\
\text { Traits and Employee } \\
\text { Voice Behavior: } \\
\text { Mediating Roles of } \\
\text { Ethical Leadership } \\
\text { and Work Group } \\
\text { Psychological Safety } \\
\text { (Walumbwa and } \\
\text { Schaubroeck, 2009) }\end{array}$ & 453 & APA \\
\hline 5 & $\begin{array}{l}\text { Human } \\
\text { Resource } \\
\text { Managem } \\
\text { ent } \\
\text { Journal }\end{array}$ & Q1 & $\begin{array}{l}13 \\
(2.9 \\
4)\end{array}$ & $\begin{array}{l}17 \\
3\end{array}$ & 6.3 & $\begin{array}{l}\text { Theorizing } \\
\text { determinants of } \\
\text { employee voice: An } \\
\text { integrative model } \\
\text { across disciplines } \\
\text { and levels of analysis } \\
\text { (Kaufman, 2015) }\end{array}$ & 49 & $\begin{array}{l}\text { Wiley- } \\
\text { Blackwell }\end{array}$ \\
\hline 6 & $\begin{array}{l}\text { Journal of } \\
\text { Industrial } \\
\text { Relations }\end{array}$ & Q1 & $\begin{array}{l}13 \\
(2.9 \\
4)\end{array}$ & $\begin{array}{l}20 \\
4\end{array}$ & 3.0 & $\begin{array}{l}\text { Changing Patterns of } \\
\text { Employee Voice: } \\
\text { Case Studies from } \\
\text { the UK and Republic } \\
\text { of Ireland } \\
\text { (Wilkinson, Dundon, } \\
\text { Marchington, } \\
\text { Ackers, 2004) }\end{array}$ & 93 & $\begin{array}{l}\text { SAGE } \\
\text { Publicatio } \\
\text { ns }\end{array}$ \\
\hline
\end{tabular}


Volume 4 Issue 13 (March 2021) PP. 01-21

DOI: 10.35631/IJEMP.413001

\begin{tabular}{|c|c|c|c|c|c|c|c|c|}
\hline 7 & $\begin{array}{l}\text { Employee } \\
\text { Relations }\end{array}$ & Q1 & $\begin{array}{l}12 \\
(2.7 \\
1)\end{array}$ & 72 & 3.1 & $\begin{array}{l}\text { Can there be non- } \\
\text { union forms of } \\
\text { workplace } \\
\text { partnership? (Dietz, } \\
\text { Cullen, Coad, 2005) }\end{array}$ & 18 & $\begin{array}{l}\text { Emerald } \\
\text { Group } \\
\text { Publishing } \\
\text { Ltd. }\end{array}$ \\
\hline 8 & $\begin{array}{l}\text { Social } \\
\text { Behavior } \\
\text { and } \\
\text { Personalit } \\
\text { y }\end{array}$ & Q3 & $\begin{array}{l}11 \\
(2.4 \\
9)\end{array}$ & 14 & 1.2 & $\begin{array}{l}\text { How } \\
\text { transformational } \\
\text { leadership influences } \\
\text { employee voice } \\
\text { behavior: The roles } \\
\text { of psychological } \\
\text { capital and } \\
\text { organizational } \\
\text { identification (Wang, } \\
\text { Zheng, Zhu, 2018) }\end{array}$ & 9 & $\begin{array}{l}\text { Society for } \\
\text { Personalit } \\
\text { y Research }\end{array}$ \\
\hline 9 & $\begin{array}{l}\text { Academy } \\
\text { of } \\
\text { Managem } \\
\text { ent } \\
\text { Journal }\end{array}$ & Q1 & $\begin{array}{l}9 \\
(2.0 \\
4)\end{array}$ & $\begin{array}{l}13 \\
64\end{array}$ & 14.0 & $\begin{array}{l}\text { Leadership behavior } \\
\text { and employee voice: } \\
\text { Is the door really } \\
\text { open? (Detert and } \\
\text { Burris, 2007) }\end{array}$ & 792 & $\begin{array}{l}\text { Academy } \\
\text { of } \\
\text { Managem } \\
\text { ent }\end{array}$ \\
\hline 10 & $\begin{array}{l}\text { Employee } \\
\text { Responsib } \\
\text { ilities and } \\
\text { Rights } \\
\text { Journal }\end{array}$ & Q3 & $\begin{array}{l}9 \\
(2.0 \\
4)\end{array}$ & $\begin{array}{l}19 \\
2\end{array}$ & 1.1 & $\begin{array}{l}\text { Employee voice to } \\
\text { supervisors } \\
\text { (Saunders, Sheppard, } \\
\text { Knight, Roth, 1992) }\end{array}$ & 107 & $\begin{array}{l}\text { Springer } \\
\text { Nature }\end{array}$ \\
\hline
\end{tabular}

Note: $\mathrm{TP}=$ Total Publication; $\mathrm{TC}=$ Total Citation

Top Nations, Collaboration, and Institutions Analysis

Based on the country-wise analysis, the extracted data in this section presented the top 15 leading nations in terms of the number of publications from Scopus. Table 3 illustrated the most productive countries that contributed to the growth of Employee Voice studies at the worldwide level sorted by TPC (total publications of the country).

In the listing by Scopus, United States tops the list with 150 publications, covering $70 \%$ of the publications globally, which indicate that the country is the key contributors in Employee Voice research. United States is followed by United Kingdom with 87 publications $(52.9 \%$ of single-country publications), China with 58 publications (56.9\% of single-country publications) and Australia with 53 publications (54.7\% of single-country publications).

There are total of seven countries (i.e., Ireland, Hong Kong, Netherlands, Germany, Taiwan, Canada and India), which have published between 13 to 19 papers. Although South Korea, Denmark, New Zealand and Pakistan were ranked among the top 15 most productive nations, they were only able to produce 8 to 9 publications. The authors contributed a more detailed information on the top 50 productive nations and institutions in the supplementary material section (Table S3). 
Table 3 also indicated that only five countries scored more than $65 \%$ of single country publications (SCP) which includes South Korea (77.8\%), Denmark (75\%), Germany (73.3\%), United States (70.6\%) and lastly, Taiwan (66.7\%). According to Khudzari et al. (2018), a high percentage of SCP is an indication that the nations had more collaborations among them. Collaborating globally within different nations are important as it carry an essential approach for knowledge sharing and great strategy to be ranked higher.

According to the World University Rankings 2019, among the productive academic institution, there were five universities ranked as the top 150 best universities (THE, 2019), which includes University of Toronto $\left(28^{\text {th }}\right)$, University of Auckland $\left(85^{\text {th }}\right)$, Hong Kong Polytechnic University $\left(106^{\text {th }}\right)$, University of Groningen $\left(120^{\text {th }}\right)$, and University of Maryland $\left(126^{\text {th }}\right)$. This result suggested that Employee Voice has been gaining interest and acknowledgement from the top global institutions.

Table 3: Leading Nations and Institutes in Employee Voice Studies

\begin{tabular}{|l|l|l|l|l|l|}
\hline Rank & Country & TPC & $\begin{array}{l}\text { SCP } \\
(\boldsymbol{\%})\end{array}$ & Productive Academic Institution & TPI \\
\hline 1 & United States & 150 & 70.6 & University of Maryland & 12 \\
\hline 2 & $\begin{array}{l}\text { United } \\
\text { Kingdom }\end{array}$ & 87 & 52.9 & Queen's University Belfast & 11 \\
\hline 3 & China & 58 & 56.9 & Renmin University of China & 4 \\
\hline 4 & Australia & 53 & 54.7 & Griffith University & 14 \\
\hline 5 & Ireland & 19 & 31.6 & National University of Ireland Galway & 9 \\
\hline 6 & Hong Kong & 18 & 11.1 & Hong Kong Polytechnic University & 7 \\
\hline 7 & Netherlands & 17 & 23.5 & University of Groningen & 6 \\
\hline 8 & Germany & 15 & 73.3 & Technische Universität Chemnitz & 3 \\
\hline 9 & Taiwan & 15 & 66.7 & $\begin{array}{l}\text { National Taiwan University of Science \& } \\
\text { Technology }\end{array}$ & 3 \\
\hline 10 & Canada & 13 & 46.1 & University of Toronto & 4 \\
\hline 11 & India & 13 & 53.8 & University of Maryland & 3 \\
\hline 12 & South Korea & 9 & 77.8 & Yeungnam University & 2 \\
\hline 13 & Denmark & 8 & 75.0 & Copenhagen Business School & 4 \\
\hline 14 & New Zealand & 8 & 37.5 & University of Auckland & 2 \\
\hline 15 & Pakistan & 8 & 50.0 & RMIT University & 2 \\
\hline
\end{tabular}

Note: TPC: total publications of the country; SCP: single-country publications; TPI: total publications of the organization 


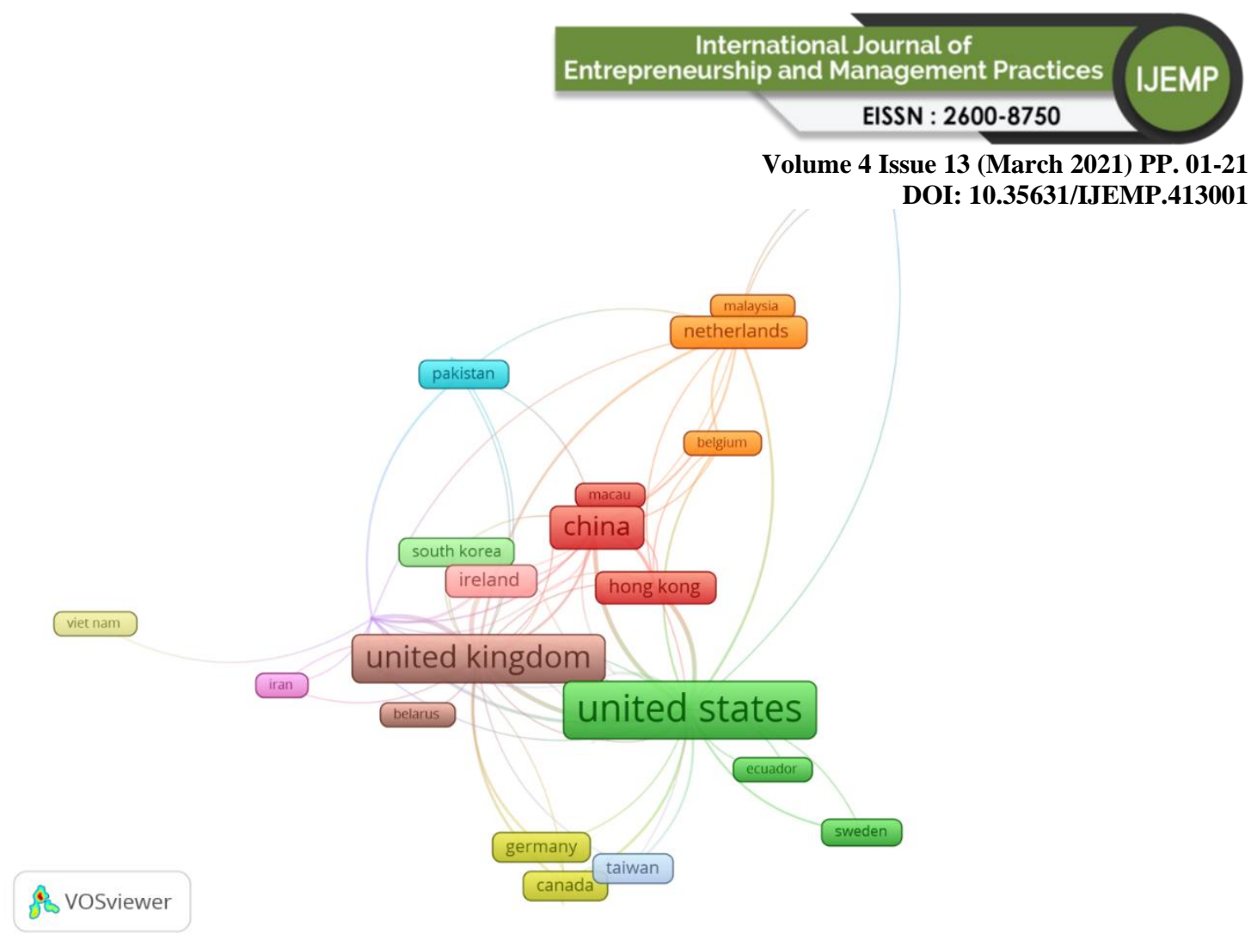

Figure 4: The Bibliometric Map Of Co-Authorships

In this section, the authors have used the VOSviewer, which is the most widely used information visualization software. Figure 4 gives the visualization of the linkages between nations. When there is a strong link between nations, the locations of those nations will be closer together (Khudzari et al., 2018). As can be seen in Figure 4, the stronger the linkage between nations, the thicker will be the line in VOSviewer. In the research area of employee voice, UK was the country with the highest publication rate, followed by US.

The co-authorship analysis showed that UK was also the country with the highest number of affiliations (23 links, 59 co-authorship), followed by US (20 links, 59 co-authorship), China (14 links, 31 co-authorship), Australia (13 links, 33 co-authorship), and others. The analysis revealed that only $10 \%$ of the nations had more than 10 international collaborative publications. In addition to that, a total of nine nations were not affiliated with any international nation in publishing employee voice papers, for example Egypt, Ghana, Nigeria, Poland, and others. It is suggested that the nine nations should collaborate by increasing the number of international students in universities, diverse working culture, improving the funding of research, and encouraging international collaborative research climate at respective working places.

\section{Most Productive and Highly Cited Authors}

The top productive authors for Scopus were extracted and sorted base on the number of publications. Table 2 help to rank the top 15 leading scholars in the area of Employee Voice. These authors are associated to seven nations including Australia (5), United States (4), United Kingdom (4), Canada (1), and Germany (1). The first publication of the leading researcher ranged between the years of 1999 to 2013, in which six of them were first author, and four of them were second author.

Wilkinson, A. is the highest contributor in Scopus database with 13 total publication and $10 \mathrm{~h}$ index, while Dundon, T. is the second highest contributor in Scopus database with 11 total publications and $7 \mathrm{~h}$-index. The next three productive authors were from United States, Tangirala, S. had a record of 10 articles and 491 total citations. Followed by Burris, E.R. with 
a record of 8 total publications and the highest number of citations among all 15 authors (TC $=1180$ ). Kassing, J.W. is the first leading author with 7 publications and $7 \mathrm{~h}$-index.

For the $6^{\text {th }}$ rank, the author is from Queen's Management School, Belfast with a record of 6 publications and $5 \mathrm{~h}$-index. The second highest number of citations among all 15 authors is Detert, J.R. $(\mathrm{TC}=1045)$ which is ranked in the $7^{\text {th }}$ place based on the total publications of six papers. Next, Donaghey, J. was the prominent researcher from University of South Australia with six publications. The following four authors (ranked at $9^{\text {th }}, 10^{\text {th }}, 11^{\text {th, }}$ and $12^{\text {th }}$ ) have total publications of five papers. Gollan, P.J. (ranked at $13^{\text {th }}$ ) with total citations of 171 and Holland, P. (ranked at $15^{\text {th }}$ ) with total citations of 130 were both from Australia with five publications. Finally, Gomez, R. is from University of Toronto, Canada with total publications of 5 papers, total citations of 90 and h-index of 4 .

It can be concluded that the following authors are the most influential authors in the area of Employee Voice as they are the most productive based on the number of papers published in Scopus and they are highly cited authors.

Table 2: The top 15 Productive Scholars in Employee Voice Research

\begin{tabular}{|c|c|c|c|c|c|c|c|c|}
\hline Rank & Author & $\begin{array}{c}\text { ID of } \\
\text { Author in } \\
\text { Scopus }\end{array}$ & $\begin{array}{c}\text { First } \\
\text { publication } \\
\text { year* }\end{array}$ & $\mathbf{T P}$ & $\begin{array}{c}\text { h- } \\
\text { index }\end{array}$ & TC & $\begin{array}{c}\text { Current } \\
\text { Affiliation }\end{array}$ & Country \\
\hline 1 & $\begin{array}{l}\text { Wilkinson, } \\
\text { A. }\end{array}$ & 7201829042 & $2004 a$ & 13 & 10 & 595 & $\begin{array}{l}\text { Griffith } \\
\text { University, } \\
\text { Brisbane }\end{array}$ & Australia \\
\hline 2 & $\begin{array}{l}\text { Dundon, } \\
\text { T. }\end{array}$ & 8330407800 & $2004 b$ & 11 & 7 & 512 & $\begin{array}{l}\text { The University } \\
\text { of Manchester, } \\
\text { Manchester }\end{array}$ & $\begin{array}{l}\text { United } \\
\text { Kingdom }\end{array}$ \\
\hline 3 & $\begin{array}{l}\text { Tangirala, } \\
\text { S. }\end{array}$ & 16053647100 & $2008 \mathrm{a}$ & 10 & 9 & 491 & $\begin{array}{l}\text { Robert H. Smith } \\
\text { School of } \\
\text { Business, } \\
\text { College Park }\end{array}$ & $\begin{array}{l}\text { United } \\
\text { States }\end{array}$ \\
\hline 4 & $\begin{array}{l}\text { Burris, } \\
\text { E.R. }\end{array}$ & 8343272000 & $2007 b$ & 8 & 8 & 1180 & $\begin{array}{l}\text { The University } \\
\text { of Texas at } \\
\text { Austin, Austin }\end{array}$ & $\begin{array}{l}\text { United } \\
\text { States }\end{array}$ \\
\hline 5 & $\begin{array}{l}\text { Kassing, } \\
\text { J.W. }\end{array}$ & 15046885400 & 2006a & 7 & 7 & 152 & $\begin{array}{l}\text { Arizona State } \\
\text { University } \\
\text { Downtown } \\
\text { Phoenix } \\
\text { Campus, } \\
\text { Phoenix }\end{array}$ & $\begin{array}{l}\text { United } \\
\text { States }\end{array}$ \\
\hline 6 & $\begin{array}{l}\text { Cullinane, } \\
\text { N. }\end{array}$ & 14031126100 & $2011 b$ & 6 & 5 & 112 & $\begin{array}{l}\text { Queen's } \\
\text { Management } \\
\text { School, Belfast }\end{array}$ & $\begin{array}{l}\text { United } \\
\text { Kingdom }\end{array}$ \\
\hline 7 & $\begin{array}{l}\text { Detert, } \\
\text { J.R. }\end{array}$ & 21833519300 & $2007 a$ & 6 & 6 & 1045 & $\begin{array}{l}\text { Darden School } \\
\text { of Business, } \\
\text { Charlottesville }\end{array}$ & $\begin{array}{l}\text { United } \\
\text { States }\end{array}$ \\
\hline
\end{tabular}




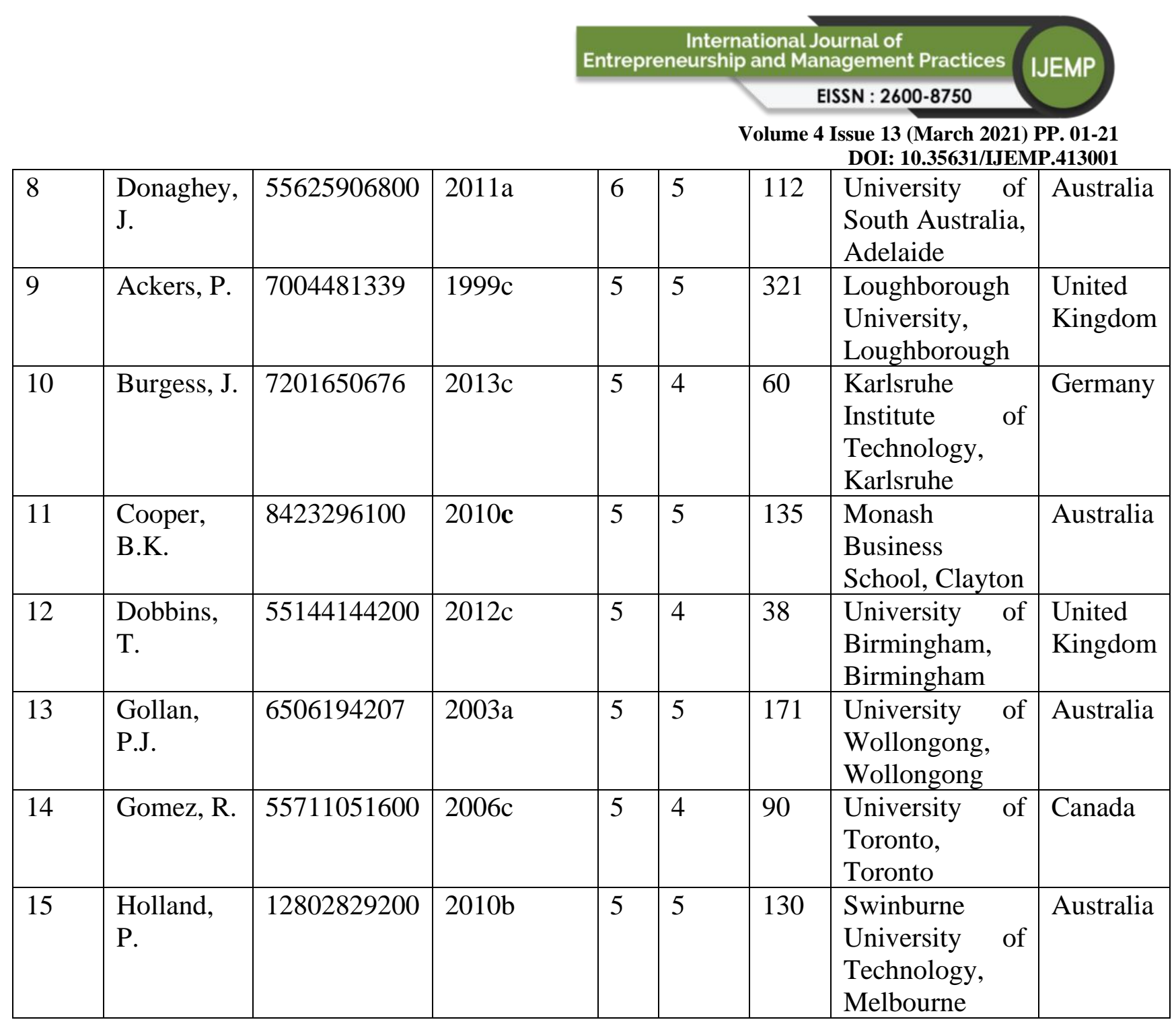

Note*= a: First Author, b: Second Author, c: Third Author and above; TP=Total Publication; TC=Total Citation

\section{Author Keywords Analysis}

Prior to developing a thesaurus file, a total of 50 author keywords was documented, in which $28 \%$ (14 author keywords) were used for five times, $16 \%$ ( 8 author keywords) were used for six times, $4 \%$ ( 2 author keywords) were used for seven times, $8 \%$ (4 author keywords) were used for eight times, 4\% (2 author keywords) were used for nine times, and 38\% (19 author keywords) were used for ten times and above. To prevent similar author keywords being analyzed, the author keywords were re-labeled in the thesaurus file. After inserting the thesaurus file, 41 author keywords (minimum five occurrences) were obtained from the new analysis.

\section{Concept and Terminology}

The analysis of author keyword co-occurrences discovered that 'employee voice' was the most frequently used keyword by the past scholars, where it had 179 occurrences and 38 links to other related keywords, as shown in Figure 5. Two types of 'employee voice' were found in author keywords, namely 'prohibitive voice' ( 8 occurrences, 6 links), and 'promotive voice' ( 8 occurrences, 6 links). Both types of employee voice shared the same occurrences and links, and similarly they have been recently researched by scholars (Average Publication Year: 2017.5). Hence, this brings a meaning that these two types of employee voice have been receiving attention in the research area of employee voice in this era. 
Volume 4 Issue 13 (March 2021) PP. 01-21

DOI: 10.35631/IJEMP.413001

In addition to that, several author keywords were found in conceptualizing the 'employee voice'. For instance, 'voice behavior' (88 occurrences, 24 links), 'employee silence' (17 occurrences, 8 links), and 'communication' ( 7 occurrences, 9 links). These keywords were frequently used by the scholars to explain 'employee voice'. For example, voice behavior is defined as the behavior of speaking up that happened without prompt and happens when employees have an opinion to be shared to improve status quo (Wong et. al, 2010). Employee voice is commonly known as one of the ways that allowing employees to communicate with organization about their opinion or feeling, hence 'communication' was found to be one of the frequent author keywords.

Besides, from the author keyword analysis, few theories were mentioned, namely leadermember exchange (LMX) theory (22 occurrences, 14 links), and social exchange theory (5 occurrences, 2 links). 'LMX' was the top four author keyword in the analysis. It brings a meaning that, the tendency to do employee voice is depending on the relationship between leader and subordinate, where the better the relationship between leader-member, the higher the chance the subordinate can voice out for themselves (Botero and Van Dyne, 2009). One of the most cited journal articles in Table 1 was related to leader-member relationship, which was "Employee voice to supervisors" by Saunders, Sheppard, Knight, and Roth (1992).

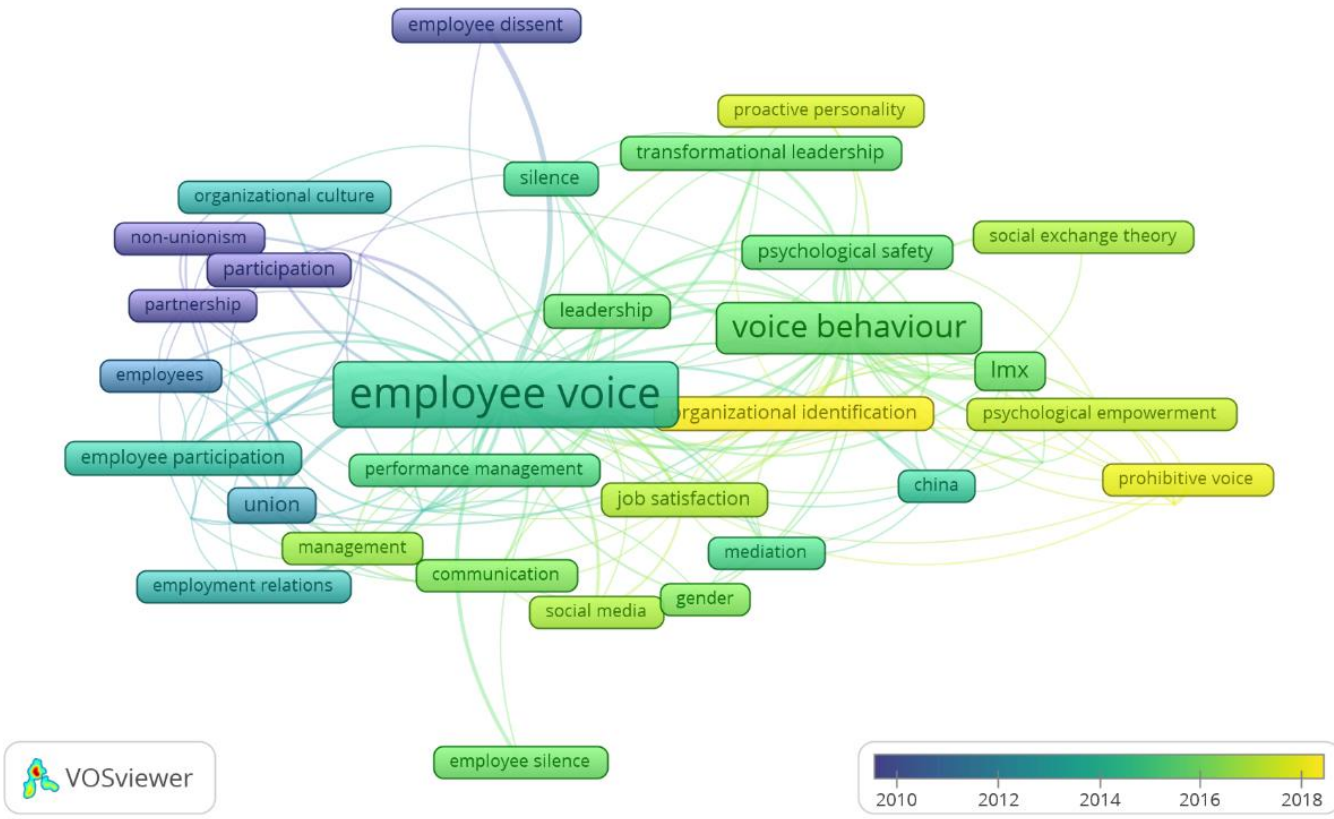

Figure 5: The Bibliometric Map of Author Keywords (Minimum Occurrences: 5)

\section{Topic of Interest}

Among the 41 author keywords, other than 'employee voice' itself, 'voice behavior' has the most occurrences (88 occurrences, 24 links). Consistent with the findings in Table 1, where one of the top three most cited papers mentioned about 'voice behavior' when they examined employee voice, namely "Leader Personality Traits and Employee Voice Behavior: Mediating Roles of Ethical Leadership and Work Group Psychological Safety" by Walumbwa and Schaubroeck (2009). The findings in Table 1 also indicated that majority of the most cited papers were about managing human resources (employees), where this is tally with the keywords occurrences of 'human resource management' (11 occurrences, 12 links) and 'management' (5 occurrences, 10 links). 
In order to do employee voice in an organization, there were few antecedents mentioned in author keyword analysis, which were leadership (14 occurrences, 11 links), leader-member relationship ( 22 occurrences, 14 links), and organizational culture (6 occurrences, 5 links). The influence of leadership has been well recognized by scholars; hence its occurrences were high in the analysis. This can be proved by referring to Table 1, where two most cited papers were about leadership, namely "Leadership behavior and employee voice: Is the door really open?" by Detert and Burris (2007), and "Leader Personality Traits and Employee Voice Behavior: Mediating Roles of Ethical Leadership and Work Group Psychological Safety" by Walumbwa and Schaubroeck (2009). According to Wåhlin-Jacobsen (2020), it is believed that if the leadership style is perceived as open in organization, employee voice activities tend to be conducted easier.

Besides leadership style, the relationship between leaders and subordinates could be the antecedent of employee voice as well. Botero and Van Dyne (2009) believed that, subordinates who have closer relationship with leaders tend to have higher opportunities to voice out their opinion, as compared to subordinates who have lower quality of relationship with leaders. Furthermore, the effectiveness of employee voice is also dependable on the organizational culture, hence 'organizational culture' is also one of the author keywords. For example, it is believed that bureaucratic culture in organization could hinder the innovativeness of ideas when employee voice was conducted (Pasha et al., 2019).

Other than antecedents of employee voice, the consequences of employee voice were mentioned in the analysis of author keyword as well. The most discussed consequence was 'employee engagement' ( 25 occurrences, 16 links), followed by 'employee participation' (21 occurrences, 11 links), 'job satisfaction' (12 occurrences, 15 links), 'organizational identification' ( 10 occurrences, 9 links), and 'employee involvement' ( 8 occurrences, 6 links). According to Ruck et al. (2017), employee engagement has been widely known as the outcome of employee voice, hence that contributed to high occurrences of 'employee engagement'. It is believed that the ability of doing employee voice in organization can boost the level of engagement among employees. Other than that, 'employee participation' and 'organizational identification' could also be seen as the common outcomes of employee voice, where each of the keyword was mentioned in most cited papers, according to Table 1. 'Employee participation' was found in "Filling the gaps: Patterns of formal and informal participation" by Townsend, Wilkinson, and Burgess (2013), while 'organizational identification' was found in "How transformational leadership influences employee voice behavior: The roles of psychological capital and organizational identification" by Wang, Zheng, and Zhu (2018). 'Job satisfaction' is another frequent keyword that was linked to employee voice. It is believed that, when employees need to conceal their feeling and opinion, their job satisfaction will be significantly decreasing as they found that their values are not aligned with organizations (Chou et al., 2019).

Besides management field, employee voice could be linked to the field of psychology as well. Few author keywords could be linked to psychology field, such as 'psychological safety' (12 occurrences, 11 links), 'proactive personality' (5 occurrences, 4 links), and 'psychological empowerment' (5 occurrences, 8 links). Personality is known as the personal traits that could affect our behavior. In the context of employee voice, it is believed that proactive personality has positive relationship with proactive behavior such as doing employee voice in organizations (Kanten and Ulker, 2012). In the context of work, psychological safety is defined Copyright (C) GLOBAL ACADEMIC EXCELLENCE (M) SDN BHD - All rights reserved 
as the perceived safety among employees to be engaged in any activities without being afraid to consequences (Subhakaran and Dyaram, 2018). The behavior of employee voice tend to be challenging instead of welcoming in organization, hence employee voice is frequently related to psychological safety, where employees will tend to voice out when they perceived they are safe to do so (Subhakaran and Dyaram, 2018). Another psychological factor that could affect employee voice is known as psychological empowerment. Psychological empowerment is defined as the intrinsic motivation that is related to the sense of control over work (Spreitzer, 1995). It is mentioned that when employees perceived high level of psychological empowerment, they tend to do employee voice more effectively and frequently ( $\mathrm{Hu}$ et al., 2018).

Other than psychological factor, the types of leadership could also affect the effectiveness of employee voice. Few types of leadership were mentioned in the author keywords analysis, namely 'ethical leadership' (11 occurrences, 9 links), 'transformational leadership (9 occurrences, 7 links), and 'paternalistic leadership' (5 occurrences, 5 links). The significance of the leadership styles effect could be seen from Table 1, where two most cited papers mentioned ethical leadership ("Leader Personality Traits and Employee Voice Behavior: Mediating Roles of Ethical Leadership and Work Group Psychological Safety" by Walumbwa and Schaubroeck, 2009) and transformational leadership ("How transformational leadership influences employee voice behavior: The roles of psychological capital and organizational identification" by Wang, Zheng, and Zhu, 2018). The similarity of these three leadership styles is, all of them are positive leadership style. This brings a meaning that, if the leaders have positive traits in leading the team, this can enhance the effectiveness of employee voice. For example, paternalistic leadership can help to improve the relationship between leader and subordinates, which in turn encouraging the climate of employee voice (Nazir et al., 2020).

Lastly, based on the author keyword analysis, it is suggested that future studies should investigate the types of employee voice. Two types of employee voice were mentioned in the analysis, namely 'prohibitive voice' ( 8 occurrences, 6 links), and 'promotive voice' (8 occurrences, 6 links). As mentioned in previous section, both types are sharing the same average publication year, which was 2017. It would be insightful for future researcher to investigate the effects of these two types of employee voice in organization, as well as the antecedents to promote promotive voice, and antecedents to eliminate prohibitive voice.

Furthermore, future scholars are also recommended to investigate employee voice in 'social media' (5 occurrences, 4 links; Average publication year: 2016.6). It can be seen that 'social media' is one of the recent (2016) keyword in the research area of employee voice, however, its occurrences are low which calling for more papers. This is because social media has been a common platform to voice out opinion in community in this era (Holland et al., 2016). A few studies were conducted recently to recognize the power of social media in helping the employees to do employee voice, such as the research work of Conway et al. (2018), as well as the work of Cassinger and Thelander (2020). Conway et al. (2019) researched about how employees voice job satisfaction and dissatisfaction via Twitter, while Cassinger and Thelander (2020) researched about the understanding of employee voice through Instagram. Cassinger and Thelander (2020) discovered that, social media can be served as a platform that provide communication between employees and management team, where the voice on social media could stimulate new insights to management team. While, surprisingly Conway et al. (2019) discovered that employees are prone to share their positive feeling and opinion on Twitter than negative feeling. In addition to that, Conway et al. (2019) also found that it was very less likely Copyright (C) GLOBAL ACADEMIC EXCELLENCE (M) SDN BHD - All rights reserved 
the employees voice out collectively on Twitter. Hence, from these two studies, it can be seen that social media is a new norm to do employee voice out, where future researchers are suggested to focus on the effectiveness of social media in employee voice.

\section{Limitations of Study}

The searching strategy is restricted for 'employee voice' to the titles and abstracts. This strategy might overlook other journal articles on 'employee voice' in Scopus database. It is believed that some scholars might exclude the keyword of 'employee voice' in their studies and opted for 'employee silence' in explaining the employees' voices by showing silence. Future scholars are suggested to compare the studies of 'employee voice' via various databases, such as combining WOS and Scopus, for the purpose to obtain a more comprehensive result.

\section{Conclusion}

This bibliometric analysis clarified the growth of 'employee voice' based on 443 related journal articles in Scopus database. Since the year 2005 till 2019, the trend of 'employee voice' has been gradually increasing as the management team started to recognize the importance of employee voice. The analysis result showed that US and UK are the leading nations in 'employee voice' area of research. Based on the co-authorship analysis, US was the nation that had the most collaboration with other international countries. Other nations such as South Africa and Sri Lanka are recommended to have more collaboration with international countries to widen their research scopes in 'employee voice'. 'Employee Voice' was found to be active in the discipline of Business Management, indicating that 'employee voice' is vital in managing the employees. Based on the author keyword occurrences analysis, it was uncovered that 'prohibitive voice' and 'promotive voice' were the new directions in examining 'employee voice'. The new variables could be a future concern in the context of organization as both variables could bring significant positive effects (promotive voice) and negative effects (prohibitive voice) to the organizational performance.

\section{References}

Aghaei Chadegani, A., Salehi, H., Yunus, M., Farhadi, H., Fooladi, M., Farhadi, M., \& Ale Ebrahim, N. (2013). A comparison between two main academic literature collections: Web of Science and Scopus databases. Asian social science, 9(5), 18-26.

Botero, I. C., \& Van Dyne, L. (2009). Employee voice behavior: Interactive effects of LMX and power distance in the United States and Colombia. Management Communication Quarterly, 23(1), 84-104.

Cassinger, C., \& Thelander, ^. (2020). Voicing the organization on Instagram: Towards a performative understanding of employee voice. Public Relations Inquiry, 9(2), 195212.

Casey, D. L., \& McMillan, G. S. (2019). Employee voice and silence: a bibliometric analysis of the literature. International Journal of Bibliometrics in Business and Management, 1(3), 251-266.

Chou, H. H., Fang, S. C., \& Yeh, T. K. (2019). The effects of facades of conformity on employee voice and job satisfaction. Management Decision.

Conway, E., Rosati, P., Monks, K., \& Lynn, T. (2019). Voicing job satisfaction and dissatisfaction through Twitter: employees' use of cyberspace. New Technology, Work and Employment, 34(2), 139-156.

Detert, J. R., \& Burris, E. R. (2007). Leadership behavior and employee voice: Is the door really open?. Academy of management journal, 50(4), 869-884. 
Dietz, G., Cullen, J., \& Coad, A. (2005). Can there be non-union forms of workplace partnership?. Employee Relations, 27(3), 289-306.

Dundon, T., Wilkinson*, A., Marchington, M., \& Ackers, P. (2004). The meanings and purpose of employee voice. The International Journal of Human Resource Management, 15(6), 1149-1170.

Holland, P., Cooper, B., \& Sheehan, C. (2017). Employee voice, supervisor support, and engagement: The mediating role of trust. Human Resource Management, 56(6), 915929.

Holland, P., Cooper, B. K., \& Hecker, R. (2016). Use of social media at work: a new form of employee voice?. The International Journal of Human Resource Management, 27(21), 2621-2634.

Hu, Y., Zhu, L., Zhou, M., Li, J., Maguire, P., Sun, H., \& Wang, D. (2018). Exploring the influence of ethical leadership on voice behavior: how leader-member exchange, psychological safety and psychological empowerment influence employees' willingness to speak out. Frontiers in psychology, 9, 1718.

Kanten, P., \& Ulker, F. E. (2012). A relational approach among perceived organizational support, proactive personality and voice behaviour. Procedia-Social and Behavioral Sciences, 62, 1016-1022.

Kaufman, B. E. (2015). Theorising determinants of employee voice: An integrative model across disciplines and levels of analysis. Human Resource Management Journal, 25(1), $19-40$.

Khudzari, J. M., Kurian, J., Tartakovsky, B., \& Raghavan, G. V. (2018). Bibliometric analysis of global research trends on microbial fuel cells using Scopus database. Biochemical engineering journal, 136, 51-60.

Kim, J., MacDuffie, J. P., \& Pil, F. K. (2010). Employee voice and organizational performance: Team versus representative influence. human relations, 63(3), 371-394.

Marchington, M. (2015). Analysing the forces shaping employee involvement and participation (EIP) at organisation level in liberal market economies (LME s). Human Resource Management Journal, 25(1), 1-18.

Nazir, S., Shafi, A., Asadullah, M. A., Qun, W., \& Khadim, S. (2020). Linking paternalistic leadership to follower's innovative work behavior: the influence of leader-member exchange and employee voice. European Journal of Innovation Management.

Pasha, M., Arshad, M., \& Saleem, N. (2019). Impact of Organizational Culture on Employee Voice: A Comparative Study of Public and Private Telecommunication Organizations in Pakistan.

Ruck, K., Welch, M., \& Menara, B. (2017). Employee voice: an antecedent to organisational engagement?. Public Relations Review, 43(5), 904-914.

Saunders, D. M., Sheppard, B. H., Knight, V., \& Roth, J. (1992). Employee voice to supervisors. Employee Responsibilities and Rights Journal, 5(3), 241-259.

Subhakaran, S. E., \& Dyaram, L. (2018). Interpersonal antecedents to employee upward voice: mediating role of psychological safety. International Journal of Productivity and Performance Management.

Spreitzer, G. M. (1995). Psychological empowerment in the workplace: Dimensions, measurement, and validation. Academy of management Journal, 38(5), 1442-1465.

Townsend, K., Wilkinson, A., \& Burgess, J. (2013). Filling the gaps: Patterns of formal and informal participation. Economic and Industrial Democracy, 34(2), 337-354.

Wang, Y., Zheng, Y., \& Zhu, Y. (2018). How transformational leadership influences employee voice behavior: The roles of psychological capital and organizational 
identification. Social Behavior and Personality: an international journal, 46(2), 313321.

Walumbwa, F. O., \& Schaubroeck, J. (2009). Leader personality traits and employee voice behavior: mediating roles of ethical leadership and work group psychological safety. Journal of applied psychology, 94(5), 1275.

Wæraas, A., \& Dahle, D. Y. (2020). When reputation management is people management: Implications for employee voice. European management journal, 38(2), 277-287.

Wilkinson, A., Barry, M., \& Morrison, E. (2019). Toward an integration of research on employee voice. Human Resource Management Review, 30(1), 100677.

Wilkinson, A., Dundon, T., Marchington, M., \& Ackers, P. (2004). Changing patterns of employee voice: Case studies from the UK and Republic of Ireland. Journal of Industrial Relations, 46(3), 298-322.

Wong, C. A., Spence Laschinger, H. K., \& Cummings, G. G. (2010). Authentic leadership and nurses' voice behaviour and perceptions of care quality. Journal of nursing management, 18(8), 889-900.

Wåhlin-Jacobsen, C. D. (2020). Open or Closed? A Social Interaction Perspective on Line Managers' Reactions to Employee Voice.Management Communication Quarterly, 34(1), 32-57.

\section{SUPPLEMENTARY MATERIALS}

Research article:

Mapping the Field: A Bibliometric Analysis of Employee Voice

Supplementary information:

Table S1: Search strategies and query strings

Table S2: The leading CiteScore journals in Employee Voice studies (Minimum 20 research articles)

Table S3: The top 50 most productive institutions in Employee Voice research

Table S1: Search Strategies And Query Strings

\begin{tabular}{|l|l|l|l|}
\hline Items & Theme & \multicolumn{1}{|c|}{ Search for: } & \multicolumn{1}{|c|}{ Query Strings } \\
\hline i. & Central & $\begin{array}{l}\text { Employee Voice } \\
\text { research articles }\end{array}$ & $\begin{array}{l}\text { (TITLE-ABS-KEY ( "Employee Voice") AND } \\
\text { DOCTYPE (ar) AND PUBYEAR > 1986 AND } \\
\text { PUBYEAR < 2020 AND ( LIMIT-TO ( } \\
\text { SRCTYPE "j" ) )YEAR > 1986 AND } \\
\text { PUBYEAR < 2020 AND (LIMIT-TO } \\
\text { (SRCTYPE, "j")) }\end{array}$ \\
\hline ii. & Central & $\begin{array}{l}\text { Non-empirical papers } \\
\text { in (i) }\end{array}$ & $\begin{array}{l}\text { (TITLE-ABS ("Employee Voice ")) AND } \\
\text { (TITLE ("recent" OR progress OR review OR } \\
\text { critical OR revisit OR advance OR development } \\
\text { OR highlight OR perspective OR prospect OR } \\
\text { trends OR bibliometric OR scientometric) OR } \\
\text { (ABS (progress OR review OR bibliometric OR } \\
\text { scientometric)) ) }\end{array}$ \\
\hline iii. & Central \\
& $\begin{array}{l}\text { Employee } \\
\text { research without non- } \\
\text { empirical papers }\end{array}$ & $\begin{array}{l}\text { (TITLE-ABS ("Employee Voice ")) AND } \\
\text { DOCTYPE (ar) AND PUBYEAR > 1986 AND } \\
\text { PUBYEAR < 2020 AND NOT EID (insert EID }\end{array}$ \\
\hline
\end{tabular}


Volume 4 Issue 13 (March 2021) PP. 01-21

DOI: 10.35631/IJEMP.413001

\begin{tabular}{|l|l|l|}
\hline & & $\begin{array}{l}\text { of review articles here*) AND (LIMIT-TO } \\
(\text { SRCTYPE, "j")) }\end{array}$ \\
\hline
\end{tabular}

Table S2: The Leading Citescore Journals In Employee Voice Studies (With Minimum Requirement Of Ten Publications And Above) Rank Based On Citescore

\begin{tabular}{|c|c|c|c|c|c|}
\hline Rank & $\begin{array}{l}\text { Name of } \\
\text { Journal }\end{array}$ & $\begin{array}{c}\text { Cite } \\
\text { Score in } \\
2019 \\
\end{array}$ & Link of Journal & Publisher & $\begin{array}{l}\text { Amount of } \\
\text { Publication }\end{array}$ \\
\hline 1 & $\begin{array}{l}\text { Journal of } \\
\text { Applied } \\
\text { Psychology }\end{array}$ & 10.7 & $\begin{array}{l}\text { https://www.apa.org/pubs/jo } \\
\text { urnals/apl/ }\end{array}$ & $\begin{array}{l}\text { American } \\
\text { Psychological } \\
\text { Association } \\
\text { Inc. }\end{array}$ & 14 \\
\hline 2 & $\begin{array}{l}\text { Human } \\
\text { Relations }\end{array}$ & 7.1 & $\begin{array}{l}\text { https://journals.sagepub.com/ } \\
\text { home/hum }\end{array}$ & $\begin{array}{l}\text { SAGE } \\
\text { Publications } \\
\text { Ltd }\end{array}$ & 14 \\
\hline 3 & $\begin{array}{l}\text { Human } \\
\text { Resource } \\
\text { Management } \\
\text { Journal }\end{array}$ & 6.3 & $\begin{array}{l}\text { https://onlinelibrary.wiley.co } \\
\text { m/journal/17488583 }\end{array}$ & $\begin{array}{l}\text { Wiley- } \\
\text { Blackwell }\end{array}$ & 13 \\
\hline 4 & $\begin{array}{l}\text { International } \\
\text { Journal of } \\
\text { Human } \\
\text { Resource } \\
\text { Management }\end{array}$ & 5.5 & $\begin{array}{l}\text { https://www.tandfonline.com } \\
\text { /toc/rijh20/current }\end{array}$ & Routledge & 32 \\
\hline 5 & $\begin{array}{l}\text { Employee } \\
\text { Relations }\end{array}$ & 3.1 & $\begin{array}{l}\text { https://www.emeraldgrouppu } \\
\text { blishing.com/journal/er }\end{array}$ & $\begin{array}{l}\text { Emerald Group } \\
\text { Publishing Ltd. }\end{array}$ & 12 \\
\hline 6 & $\begin{array}{l}\text { Economic and } \\
\text { Industrial } \\
\text { Democracy }\end{array}$ & 3.0 & $\begin{array}{l}\text { https://journals.sagepub.com/ } \\
\text { home/eid }\end{array}$ & $\begin{array}{l}\text { SAGE } \\
\text { Publications } \\
\text { Ltd }\end{array}$ & 17 \\
\hline 7 & $\begin{array}{ll}\text { Journal } & \text { of } \\
\text { Industrial } \\
\text { Relations }\end{array}$ & 3.0 & $\begin{array}{l}\text { https://journals.sagepub.com/ } \\
\text { home/jir }\end{array}$ & $\begin{array}{l}\text { SAGE } \\
\text { Publications } \\
\text { Inc. }\end{array}$ & 13 \\
\hline 8 & $\begin{array}{l}\text { Social } \\
\text { Behavior and } \\
\text { Personality }\end{array}$ & 1.2 & $\begin{array}{l}\text { https://www.sbp- } \\
\text { journal.com/index.php/sbp }\end{array}$ & $\begin{array}{ll}\text { Society for } \\
\text { Personal } \\
\text { Research }\end{array}$ & 11 \\
\hline
\end{tabular}


Volume 4 Issue 13 (March 2021) PP. 01-21

DOI: 10.35631/IJEMP.413001

Table S3: The top 50 most productive institutions in Employee Voice Research

\begin{tabular}{|c|c|c|c|}
\hline Rank & Institution & Country & $\begin{array}{c}\text { No. of } \\
\text { Publications }\end{array}$ \\
\hline 1 & Griffith University & Australia & 15 \\
\hline 2 & University of Maryland & United States & 12 \\
\hline 3 & Queen's University Belfast & $\begin{array}{l}\text { United } \\
\text { Kingdom }\end{array}$ & 11 \\
\hline 4 & The University of Texas at Austin & United States & 10 \\
\hline 5 & Monash University & Malaysia & 10 \\
\hline 6 & University of Warwick & $\begin{array}{l}\text { United } \\
\text { Kingdom }\end{array}$ & 10 \\
\hline 7 & National University of Ireland Galway & $\begin{array}{l}\text { United } \\
\text { Kingdom }\end{array}$ & 9 \\
\hline 8 & Robert H. Smith School of Business & United States & 9 \\
\hline 9 & Hong Kong Polytechnic University & Hong Kong & 8 \\
\hline 10 & Michigan State University & United States & 8 \\
\hline 11 & London School of Economics and Political Science & $\begin{array}{l}\text { United } \\
\text { Kingdom }\end{array}$ & 7 \\
\hline 12 & The University of Manchester & $\begin{array}{l}\text { United } \\
\text { Kingdom }\end{array}$ & 6 \\
\hline 13 & University of Groningen & Netherlands & 6 \\
\hline 14 & King's College London & $\begin{array}{l}\text { United } \\
\text { Kingdom }\end{array}$ & 6 \\
\hline 15 & Macquarie University & Australia & 6 \\
\hline 16 & New York University & United States & 6 \\
\hline 17 & Dublin City University & $\begin{array}{l}\text { United } \\
\text { Kingdom }\end{array}$ & 6 \\
\hline 18 & Bangor University & $\begin{array}{l}\text { United } \\
\text { Kingdom }\end{array}$ & 6 \\
\hline 19 & Alliance Manchester Business School & $\begin{array}{l}\text { United } \\
\text { Kingdom }\end{array}$ & 6 \\
\hline 20 & University of Cambridge & United States & 6 \\
\hline 21 & Curtin University & Australia & 6 \\
\hline 22 & University of South Australia & Australia & 6 \\
\hline 23 & $\begin{array}{l}\text { Loughborough University, School of Business and } \\
\text { Economics }\end{array}$ & $\begin{array}{l}\text { United } \\
\text { Kingdom }\end{array}$ & 6 \\
\hline 24 & RMIT University & United States & 5 \\
\hline 25 & Indiana University Bloomington & United States & 5 \\
\hline 26 & McCombs School of Business & United States & 5 \\
\hline 27 & Cornell SC Johnson College of Business & United States & 5 \\
\hline 28 & DCU Business School & $\begin{array}{l}\text { United } \\
\text { Kingdom }\end{array}$ & 5 \\
\hline 29 & University of Illinois at Urbana-Champaign & United States & 4 \\
\hline 30 & Pennsylvania State University & United States & 4 \\
\hline
\end{tabular}


Volume 4 Issue 13 (March 2021) PP. 01-21

DOI: 10.35631/IJEMP.413001

\begin{tabular}{|l|l|l|c|}
\hline 31 & The University of Sheffield & $\begin{array}{l}\text { United } \\
\text { Kingdom }\end{array}$ & 4 \\
\hline 32 & Arizona State University West Campus & United States & 4 \\
\hline 33 & NC State University & United States & 4 \\
\hline 34 & Renmin University of China & China & 4 \\
\hline 35 & University of Toronto & Canada & 4 \\
\hline 36 & Copenhagen Business School & Denmark & 4 \\
\hline 37 & Sun Yat-Sen University & China & 4 \\
\hline 38 & Beijing Jiaotong University & China & 4 \\
\hline 39 & ETH Zürich & Switzerland & 4 \\
\hline 40 & University of Southern California & United States & 4 \\
\hline 41 & University of Minnesota Twin Cities & United States & 4 \\
\hline 42 & University of Georgia & United States & 4 \\
\hline 43 & Central Washington University & United States & 4 \\
\hline 44 & Leonard N. Stern School of Business & United States & 4 \\
\hline 45 & Sheffield University Management School & United & 4 \\
& & Kingdom & \\
\hline 46 & Queen's Management School & United & 4 \\
\hline 47 & Griffith Business School & Kingdom & \\
\hline 48 & Vanderbilt University & Australia & 4 \\
\hline 49 & Zhejiang University & United States & 3 \\
\hline 50 & University of Pennsylvania & China & 3 \\
\hline & & United States & 3 \\
\hline
\end{tabular}

